21. The Lancet. The final verdict on Paolo Macchiarini: guilty of misconduct. Lancet. 2018;392:2.

22. The Lancet E. Retraction-Tracheobronchial transplantation with a stem-cellseeded bioartificial nanocomposite: a proof-of-concept study. Lancet. 2018;392:11.

23. Erratum. Retracted: Airway transplantation. Thorac Surg Clin. 2018;28. xi.

24. Gerdin B. Investigation of scientific misconduct. Statement of opinion on assignment ref: 2-2184/2014. 2015. Available at: http://www.circare.org/info/ pm/gerdin-finalrpt-20150513.pdf. Accessed December 7, 2016.

25. Expert Group on Misconduct in Research. The Ethics Review Appeals Board in Sweden. Statement Ref no. O 12-20162017. Available at: https://drive.google. com/file/d/0By2HqPi4t2RbYzZweVRieVVMajhJQUM0cmFMekwyRVJTUFVr/ view. Accessed October 20, 2017.

26. Ajalloueian F, Lim ML, Lemon G, Haag JC, Gustafsson Y, Sjöqvist S, et al. Retraction notice to: "Biomechanical and biocompatibility characteristics of electrospun polymeric tracheal scaffolds" [BIOMATERIALS 35/20 (2014) 5307-5315]. Biomaterials. 2019;199:89.

27. Jungebluth P, Haag JC, Lim ML, Lemon G, Sjöqvist S, Gustafsson Y, et al Retraction notice to: "Verification of cell viability in bioengineered tissues and organs before clinical transplantation" [BIOMATERIALS (2013) 4057-4067]. Biomaterials. 2019;199:88.
28. The Lancet Editors. Retraction-Engineered whole organs and complex tissues Lancet. 2018:392:11.

29. Sigurdsson MI, Sigurdsson H, Hreinsson K, Simonardottir L, Gudbjartsson T. Bronchiovenous fistula causing bleeding and air embolism: an unusual complication of bronchoscopic tumor resection. Am J Respir Crit Care Med. 2011;183:681-2.

30. Jungebluth P, Macchiarini P. Airway transplantation. Thorac Surg Clin. 2014;24: 97-106.

31. Zimmerli W, Sendi P. Pathogenesis of implant-associated infection: the role of the host. Semin Immunopathol. 2011;33:295-306.

32. Ma H, Galvin TA, Glasner DR, Shaheduzzaman S, Khan AS. Identification of a novel rhabdovirus in Spodoptera frugiperda cell lines. J Virol. 2014;88: 6576-85.

33. Geisler C, Jarvis DL. Rhabdovirus-like endogenous viral elements in the genome of Spodoptera frugiperda insect cells are actively transcribed: implications for adventitious virus detection. Biologicals. 2016;44:219-25.

Key Words: tracheal replacement, tracheal prosthesis, synthetic tracheal graft, airway surgery
See Article page 2525 .

\section{Commentary: The sobering truth about tracheal regeneration}

\author{
Pierre R. Delaere, $\mathrm{MD}, \mathrm{PhD},{ }^{\mathrm{a}}$ and \\ Dirk Van Raemdonck, $\mathrm{MD}, \mathrm{PhD}^{\mathrm{b}}$
}

Tracheal replacement to restore functional integrity of a long segmental defect or a complex airway stenosis remains a surgical challenge. ${ }^{1}$ A variety of surgical techniques have been reported clinically, including transplantation of autologous $^{2}$ or heterologous ${ }^{3}$ tissue flaps, direct ${ }^{4,5}$ or indirect ${ }^{6}$ cadaveric tracheal allografting, and interposition of a "regenerated" trachea."

In this issue of the Journal, Fux and colleagues ${ }^{8}$ from the Karolinska Institute in Stockholm publish a very detailed and well-illustrated long-term follow-up of 3 patients who received a "bioengineered tracheal allograft seeded with

\footnotetext{
From the Departments of ${ }^{\mathrm{a}}$ Oto-Rhino-Laryngology and ${ }^{\mathrm{b}}$ Thoracic Surgery, University Hospitals Leuven, Leuven, Belgium.

Disclosures: Authors have nothing to disclose with regard to commercial support.

Received for publication Oct 27, 2019; revisions received Oct 27, 2019; accepted for publication Oct 28, 2019; available ahead of print Dec 4, 2019.

Address for reprints: Dirk Van Raemdonck, MD, PhD, Department of Thoracic Surgery, University Hospital Gasthuisberg, Herestraat 49, B-3000 Leuven, Belgium (E-mail: dirk.vanraemdonck@uzleuven.be).

J Thorac Cardiovasc Surg 2020;159:2537-9

$0022-5223 / \$ 36.00$

Copyright (c) 2019 by The American Association for Thoracic Surgery

https://doi.org/10.1016/j.jtcvs.2019.10.116
}

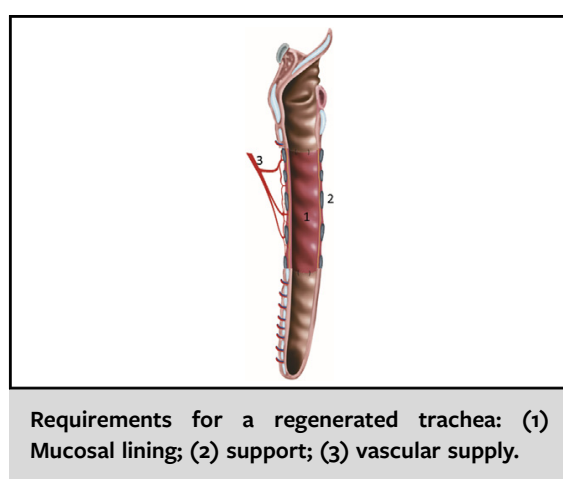

CENTRAL MESSAGE

Tracheal replacement remains a surgical challenge. Synthetic tracheas and nonvascularized donor tracheas are destined to fail and will never transform into a living functional organ.

bone marrow cells" resulting in numerous complications and finally fatal outcome. These authors from Karolinska institute should be congratulated for their courage. However, the patients involved shouldn't have undergone this procedure. The devastating outcome after the implantation of a synthetic trachea was fully predictable. In fact, the 


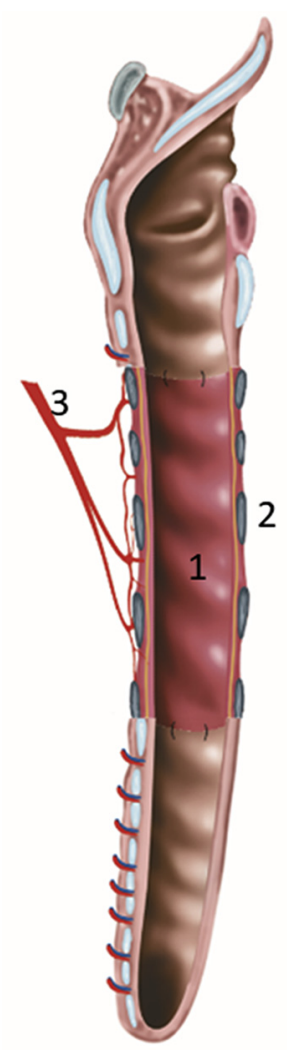

FIGURE 1. Requirements for a regenerated trachea: (1) Mucosal lining; (2) support; (3) vascular supply.

"bioengineered tracheal allograft seeded with bone marrow cells" was nothing more than a plastic tube. ${ }^{8}$

In 2008, a high-profile paper was published on the first successful regeneration of the trachea. ${ }^{7}$ In this case report, 2 miracles had occurred: (1) The cells of a donor trachea had been replaced by recipient cells after applying stem cells of the recipient to an enzymatically treated cadaver donor trachea; and (2) The "regenerated" trachea could be used for airway repair without restoration of its blood supply.

The paper attracted much media attention as the first organ that could be regenerated; it was foreseen that other holloworgan regenerations would quickly follow. ${ }^{9}$ Indeed, the engineered trachea was seen to be the first step toward other forms of organ regeneration. Classic organ transplantations with their typical side effects due to antirejection medication could then be replaced by growing organs from the body's own cells.

However, the problem with the tracheal regeneration concept, portrayed as successful, is that it is theoretically impossible. All requirements necessary to consider tracheal regeneration were lacking (Figure 1). More misleading highprofile papers were subsequently published in Lancet as the first "regenerated" synthetic trachea ${ }^{10}$ and the first "regenerated" cadaver trachea in a child. ${ }^{11}$ Since 2008 , about 20 patients received a "regenerated" trachea in different centers around the world. As could be expected, severe complications arose, with fatal outcomes in the majority of the patients. ${ }^{12}$ The tracheal replacements were initially published as successful in some patients because of the use of a stent and the omental wrapping, which delayed the inevitable complications (Figure 2).

From the very beginning, we have tried to inform the medical world about this blatant example of scientific deception. $^{13,14}$ From 2014 onwards, 4 whistleblowers of the Karolinska Institute, and the authors of this current paper in the Journal, joined us in these actions. We had to wait for a reaction from the involved institutions until January 2016, when the scandal was exposed to a wider audience after a 3-hour documentary that was aired on Swedish national television and on BBC. The overwhelming documentary resulted from

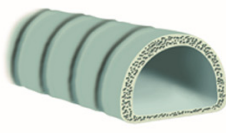

Synthetic trachea

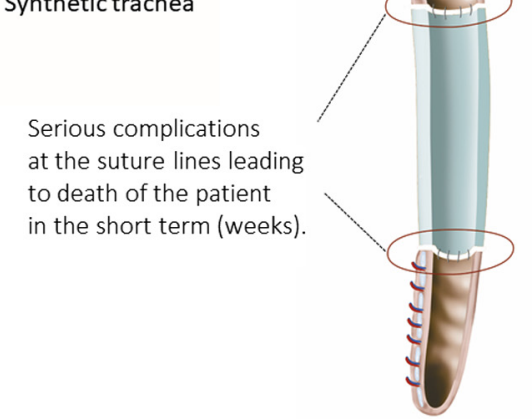

Synthetic trachea inside the airway

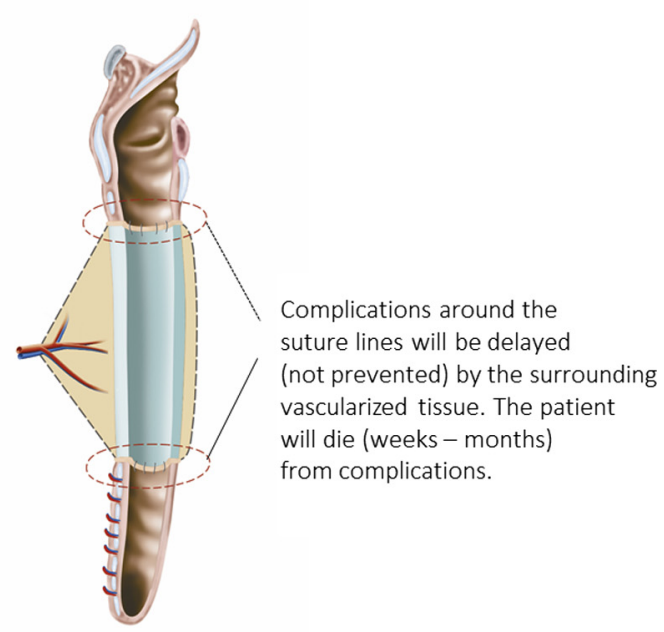

Synthetic trachea wrapped with vascularized tissue (omentum).

FIGURE 2. Left, nude synthetic trachea: suture lines will never heal, leading to anastomotic breakdown (red circles) with serious complications in the short term. Right, synthetic trachea wrapped with vascularized tissue (eg, omentum): suture lines will not heal. Anastomotic breakdown (red circles) will be delayed by surrounding vascularized tissue. Serious complications will occur in the long term. 
top-shelf investigative journalism. Quickly after its broadcasting, board members of the Karolinska Institute, including the secretary-general of the Nobel Committee, had to resign and the paper on the regenerated synthetic trachea was retracted. ${ }^{15,16}$

This misleading story on tissue regeneration hasn't come to an end yet. Until now, other papers on the regenerated cadaver trachea still stay afloat. Synthetic tracheas and nonvascularized donor tracheas are destined to fail. They were wrongfully used for tracheal replacement and presented as breakthroughs in clinical tracheal tissue engineering.

\section{References}

1. Grillo HC. Tracheal replacement: a critical review. Ann Thorac Surg. 2002;73: 1995-2004.

2. Mercier O, Kolb F, Dartevelle PG. Autologous tracheal replacement: surgical technique and outcome. Thorac Surg Clin. 2018;28:347-55.

3. Wurtz A, Porte H, Conti M, Desbordes J, Copin MC, Azorin J, et al. Tracheal replacement with aortic allografts. $N$ Engl J Med. 2006;355:1938-40.

4. Rose KG, Sesterhenn K, Wustrow F. Tracheal allotransplantation in man. Lancet. 1979;1:433.

5. Levashov YN, Yablonsky PK, Cherny SM, Orlov SV, Shafirovsky BB, Kuznetzov IM. One stage allotransplantation of thoracic segment of the trachea in a patient with idiopathic fibrosing mediastinitis and marked tracheal stenosis. Eur J Cardiothorac Surg. 1993;7:383-6.
6. Delaere P, Vranckx J, Verleden G, De Leyn P, Van Raemdonck D. Leuven Tracheal Transplant Group. Tracheal allotransplantation after withdrawal of immunosuppressive therapy. N Engl J Med. 2010;362:138-45.

7. Macchiarini P, Jungebluth P, Go T, Asnaghi MA, Rees LE, Cogan TA, et al. Clin ical transplantation of a tissue-engineered airway. Lancet. 2008;372:2023-30.

8. Fux T, Österholm C, Themudo R, Simonson O, Grinnemo K-H, Corbascio M Synthetic tracheal grafts seeded with bone marrow cells fail to generate functional tracheae: first long-term follow-up study. J Thorac Cardiovasc Surg. 2020;159:2525-37.e23.

9. Fountain H. A first: organs tailor-made with body's own cells. The New York Times. September 15, 2012:A1. Available at: https://www.nytimes.com/2012/ 09/16/health/research/scientists-make-progress-in-tailor-made-organs.html. Accessed October 27, 2019.

10. Jungebluth P, Alici E, Baiguera S, Blomberg P, Bozóky B, Crowley C, et al. Tracheobronchial transplantation with a stem-cell-seeded bioartificial nanocomposite: a proof-of-concept study. Lancet. 2011;378:1997-2004.

11. Elliott MJ, De Coppi P, Speggiorin S, Roebuck D, Butler CR, Samuel E, et al, Stem-cell-based tissue engineered tracheal replacement in a child: a 2-year follow-up study. Lancet. 2012;380:994-1000.

12. The For Better Science blog, "Macchiarini's trachea transplant patients: the full list." Available at: https://forbetterscience.com/2017/06/16/macchiarinis-tracheatransplant-patients-the-full-list/. Accessed October 27, 2019.

13. Delaere PR, Van Raemdonck D. The trachea: the first tissue-engineered organ? J Thorac Cardiovasc Surg. 2014;147:1128-32.

14. Delaere P. Stem-cell "hype" in tracheal transplantation? Transplantation. 2010; 90:928-9.

15. The Lancet Editors. Retraction - Tracheobronchial transplantation with a stem-cellseeded bioartificial nanocomposite: a proof-of-concept study. Lancet. 2018;392:11. 16. Horton R. Offline: Paolo Macchiarini-science in conflict. Lancet. 2016;20:387.

\section{Commentary: Trust but verify- How do we keep the faith?}

Susan D. Moffatt-Bruce, MD, PhD, MBA, ${ }^{a}$ Thomas A. D'Amico, MD, ${ }^{\mathrm{b}}$ Richard D. Weisel, MD, ${ }^{\mathrm{c}}$ and Robert M. Sade, MD $^{\mathrm{d}}$

In this month's Journal, Fux and colleagues ${ }^{1}$ report the first long-term follow-up study of the outcome of synthetic

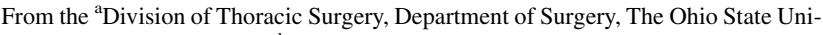
versity, Columbus, Ohio; ${ }^{\mathrm{b}}$ Section of General Thoracic Surgery, Duke University Medical Center, Durham, NC; ${ }^{\mathrm{c}}$ Toronto General Hospital and Research Institute, University of Toronto, Toronto, Ontario, Canada; and ${ }^{\mathrm{d}}$ Division of Cardiothoracic Surgery, Department of Surgery, Institute of Human Values in Health Care, Medical University of South Carolina, Charleston, SC.

Disclosures: Authors have nothing to disclose with regard to commercial support.

Received for publication Oct 19, 2019; revisions received Oct 19, 2019; accepted for publication Oct 21, 2019; available ahead of print Jan 8, 2020.

Address for reprints: Susan D. Moffatt-Bruce, MD, PhD, MBA, Division of Thoracic Surgery, Department of Surgery, 168 Doan Hall, 410 W 10th Ave, Columbus, OH 43210 (E-mail: Susan.moffatt-bruce@osumc.edu).

J Thorac Cardiovasc Surg 2020;159:2539-40

$0022-5223 / \$ 36.00$

Copyright (c) 2019 by The American Association for Thoracic Surgery

https://doi.org/10.1016/j.jtcvs.2019.10.113
}

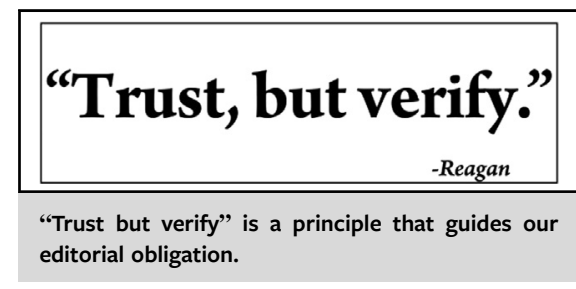

CENTRAL MESSAGE

Dissemination of innovation and
research is the raison d'être of
surgical journals; however, all
scientific findings must be
continually challenged and
questioned to ensure their
veracity.

tracheal grafts seeded with bone marrow cells at their institution. Their outcome data contradict previously reported successes with this technique. ${ }^{2-5}$ Fux and colleagues ${ }^{1}$ demonstrate that these grafts were not cellularized with site-specific cells and did not become living, functional 